\title{
PENGARUH CORPORATE SOCIAL RESPONSIBILITY TERHADAP KUALITAS LABA (STUDI EMPIRIS PADA PERUSAHAAN-PERUSAHAAN SELAIN INDUSTRI KEUANGAN YANG TERDAFTAR DI BEI)
}

\section{THE INFLUENCE OF CORPORATE SOCIAL RESPONSIBILITY ON PROFIT QUALITY (EMPIRICAL STUDY ON COMPANIES OTHER THAN THE FINANCIAL INDUSTRY REGISTERED IN THE BEI)}

\author{
A. J. Aziz, D. A. Faisol \\ Magister Akuntansi, Fakultas Ekonomi dan Bisnis, Universitas Mercu Buana \\ Ayi_aziz@yahoo.com.sg
}

\begin{abstract}
CSR is a manifestation of business ethics to discuss the value, whether a company adheres to the value of a good or bad. Good CSR is that integrating the principles of good corporate governance, namely fairness, transparency, accountability and responsibility. With this concept, the CSR activity becomes interesting to study, especially when linked with the quality of financial reporting is usually measured by the quality of earnings. Previous research has been done to investigate the effects of CSR on the quality of earnings with mixed results and still contradictory. Therefore, this study was conducted to reexamine the influence of CSR on the quality of financial reporting with earnings quality proxies. The sample in this study are the companies listed on the Indonesia Stock Exchange outside the financial industry, specifically publishes CSR report or sustainability report.

Results of this study found that companies with good CSR levels are more likely not to engage in earnings management activity, have accrued value of more persistent and have a better quality of accruals. These results are consistent with the notion Kim, Park, and Wier (2012), the CSR activities are motivated by the incentive manager to be honest, trustworthy and ethical, so that companies are more cautious in making financial reports to serve the interests of stakeholders.
\end{abstract}

Keywords: CSR, Sustainability Reporting, Earnings Quality, Conditional Revenue Model, Accrual Persistence, Quality of Accruals.

\section{ABSTRAK}

CSR adalah manifestasi etika bisnis untuk membahas nilai, apakah perusahaan menganut nilai baik atau buruk. CSR yang baik adalah yang mengintegrasikan prinsip-prinsip tata kelola perusahaan yang baik, yaitu keadilan, transparansi, akuntabilitas dan tanggung jawab. Dengan konsep ini, aktivitas CSR menjadi menarik untuk dikaji, terutama ketika dikaitkan dengan kualitas pelaporan keuangan yang biasanya diukur oleh kualitas penghasilan. Penelitian sebelumnya telah dilakukan untuk menyelidiki efek CSR pada kualitas penghasilan dengan hasil yang beragam dan masih kontradiktif. Oleh karena itu, penelitian ini dilakukan untuk menguji kembali pengaruh CSR terhadap kualitas pelaporan keuangan dengan proksi kualitas laba. Sampel dalam penelitian ini adalah perusahaan yang terdaftar di Bursa Efek Indonesia di luar industri keuangan, secara khusus menerbitkan laporan CSR atau laporan keberlanjutan.

Hasil dari penelitian ini menemukan bahwa perusahaan dengan tingkat CSR yang baik lebih cenderung tidak terlibat dalam aktivitas manajemen laba, memiliki nilai yang masih harus lebih persisten dan memiliki kualitas akrual yang lebih baik. Hasil ini konsisten dengan gagasan Kim, Park, dan Wier (2012), kegiatan CSR dimotivasi oleh manajer insentif untuk jujur, dapat dipercaya dan etis, sehingga perusahaan lebih berhati-hati dalam membuat laporan keuangan untuk melayani kepentingan pemangku kepentingan. .

Kata kunci : CSR, Pelaporan Keberlanjutan, Kualitas Penghasilan, Model Penerimaan Bersyarat, Persistensi Akrual, Kualitas Akrual. 


\section{PENDAHULUAN}

\subsection{Latar Belakang}

Corporate Social Responsibility (CSR) telah menjadi istilah yang populer dan semakin digunakan diantara perusahaan, pemerintah dan pers dalam beberapa tahun terakhir (DitlevSimonsen, 2011, dalam Salewski et al., 2014). Harvard Kennedy School mengeluarkan definisi yang kredibel dan lengkap yang melihat CSR sebagai suatu strategi. CSR tidak hanya terkait dengan keuntungan suatu perusahaan, tetapi juga bagaimana keuntungan tersebut dihasilkan. CSR mencakup lebih dari sekadar kedermawanan dan kepatuhan (Patoni \& Lasmana, 2018). Selain itu, CSR juga dipandang sebagai suatu cara untuk membantu perusahaan mengelola dampak ekonomi, sosial, dan lingkungan, beserta hubungan perusahaan dengan lingkungan kerja, pasar, supply chain, komunitas, dan domain kebijakan publik (Rahman, 2013). Dengan demikian perusahaan diharapkan mampu menyeimbangkan kebutuhan sosial dan pertumbuhan ekonomi melalui peran strategik dan kompetitif dari responsibilty perusahaan untuk keberlangsungan perusahaan kedepannya (Dincer, 2011 dalam Handajani et al., 2014).

Hadi (2011) mengatakan bahwa inti praktek social responsibility dari perusahaan adalah persoalan etika bisnis (business ethic). Mengingat, pelaksanaannya tidak dapat dilepaskan dari panggilan nurani pelaku bisnis. Menurut Supomo (2004) dalam Suharto (2008), CSR yang baik adalah CSR yang memadukan empat prinsip good corporate governance, yakni fairness, transparency, accountability dan responsibility, secara harmonis. Ada perbedaan mendasar diantara keempat prinsip tersebut. Tiga prinsip pertama cenderung bersifat shareholdersdriven, karena lebih memerhatikan kepentingan pemegang saham perusahaan. Sebagai contoh, fairness bisa berupa perlakuan yang adil terhadap pemegang saham minoritas; transparency menunjuk pada penyajian laporan keuangan yang akurat dan tepat waktu; sedangkan accountability diwujudkan dalam bentuk fungsi dan kewenangan RUPS, komisaris, dan direksi yang harus dipertanggungjawabkan. Sementara itu, prinsip responsibility lebih mencerminkan stakeholdersdriven, karena lebih mengutamakan pihak-pihak yang berkepentingan terhadap eksistensi perusahaan. Stakeholders perusahaan bisa mencakup karyawan beserta keluarganya, pelanggan, pemasok, komunitas setempat dan masyarakat luas, termasuk pemerintah selaku regulator.

Perusahaan-perusahaan yang menjalankan $C S R$ yang baik dan bertanggungjawab diharapkan dapat menyajikan laporan keuangan yang transparan dan berkualitas, sehingga dapat memfasilitasi para pengguna laporan keuangan dalam pengambilan keputusan. Skandal akuntansi yang berkaitan dengan kualitas informasi keuangan, seperti kasus yang terjadi pada perusahaan multinasional yaitu kasus Enron, World Com, Xerox dan perusahaan nasional seperti Kimia Farma dan Lippo Bank diharapkan tidak akan terjadi lagi dikemudian hari.

Banyak penulis telah meneliti hubungan antara CSR dan kinerja keuangan dan "dalam ringkasan" menemukan hubungan positif (Salewski et al., 2014). Lebih lanjut Salewski et al. (2014) menyatakan, penelitian tentang hubungan antara CSR dan kinerja keuangan tidak mencerminkan apakah peningkatan CSR benarbenar menyebabkan perubahan dalam perusahaan. Oleh karena itu, peneliti yang lain menyelidiki hubungan CSR yang biasanya diukur dengan kualitas laba (earnings quality).

Penelitian merujuk kepada penelitian yang dilakukan oleh Marcus Salewski \& Henning Zulch (2014), yang meneliti "Hubungan antara CSR dengan kualitas laba", lebih tepatnya terkait tingkat manajemen laba, tingkat konservatisme akuntansi dan kualitas akrual. Mereka menemukan rating CSR perusahaan yang tinggi lebih mungkin untuk terlibat dalam manajemen laba, melaporkan kabar buruk (bad news) tidak tepat waktu dan rendahnya kualitas akrual yang dimiliki.

Perbedaan penelitian ini dengan penelitian sebelumnya Salewski et al. (2014), adalah pada penelitian Salewski et al. (2014) CSR diukur melalui CSR ranking dengan menggunakan data CSR dari Kirchhoff Consult AG, sebuah perusahaan konsultan di Jerman yang menerbitkan CSR ranking kepada 90 perusahaan besar di Eropa. Dalam penelitian ini $C S R$ diukur menggunakan indeks $C S R$ yang pengungkapannya disyaratkan pada Global Reporting Initiative. Salewski et al. (2014) menggunakan pendekatan discretionary accruals, accounting conservatism dan quality of accruals.

Atas dasar perkembangan CSR yang semakin populer, dan untuk melihat konsistensi hasil penelitian-penelitian sebelumnya yang masih beragam, maka penulis tertarik untuk melakukan penelitian kembali mengenai "Pengaruh 
Corporate Social Responsibility Terhadap Kualitas Laba", dengan rumusan masalah sebagai berikut:

1. Apakah $C S R$ berpengaruh terhadap kualitas laba yang diukur dengan pendekatan Conditional Revenue Model, dengan Size, Leverage dan Growth sebagai variabel kontrol pada perusahan-perusahaan selain industri keuangan yang terdaftar di BEI ?

2. Apakah $C S R$ berpengaruh terhadap variabel Y melalui pendekatan Accrual Persistence dengan Size, Leverage dan Growth sebagai variabel kontrol. ?

3. Apakah $C S R$ berpengaruh terhadap variabel Y melalui pendekatan Quality of Accruals dengan Size, Leverage dan Growth sebagai variabel kontrol ?

\subsection{Tujuan Penelitian}

Berdasarkan latar belakang dan rumusan masalah, tujuan penelitian ini untuk mengetahui pengaruh CSR terhadap kualitas laba yang diukur dengan:

1. Pendekatan Conditional Revenue Model dengan Size, Leverage dan Growth sebagai variabel kontrol.

2. Pendekatan Accrual Persistence dengan Size, Leverage dan Growth sebagai variabel kontrol.

3. Pendekatan Quality of Accruals dengan Size, Leverage dan Growth sebagai variabel kontrol.

\section{KAJIAN PUSTAKA}

\subsection{Konsep Corporate Social Responsibility}

Harvard's Kennedy School of Government (2009), dalam Rahman (2013), mengemukakan bahwa: "CSR, menurut mereka, tidak hanya meliputi apa yang dilakukan perusahaan dengan keuntungan mereka, tetapi juga bagaimana keuntungan tersebut dihasilkan. CSR mencakup lebih dari sekadar kedermawanan dan kepatuhan. Carroll (1979, 1991) dalam Salewski et al., (2014), mengemukakan CSR terdiri dari empat tanggung jawab korporasi, yaitu (1) ecomomic responsibilities, tanggung jawab ekonomi yang menguntungkan, (2) legal responsibilities, dalam menjalankan usahanya perusahaan harus mampu memenuhi tanggung jawab hukum dengan mematuhi peraturan perundang-undangan yang berlaku, (3) ethical responsibilities, dalam menjalankan usahanya perusahaan harus melakukan apa yang benar dan adil, (4) philanthropic responsibilities, perusahaan harus menjadi warga korporasi yang baik dengan menyumbangkan sumber daya untuk berbagai macam tujuan sosial, pendidikan, rekreasi dan budaya.

\subsection{Teori Legitimasi (Legitimacy Theory)}

CSR dalam pandangan legitimacy theory, menurut Gary O' Donovan (2002), dalam Hadi (2011), mengemukakan bahwa CSR merupakan strategi legitimasi, yaitu cara untuk mengurangi senjangan legitimasi (legitimacy gap), seperti diilustrasikan dalam diagram di bawah ini.

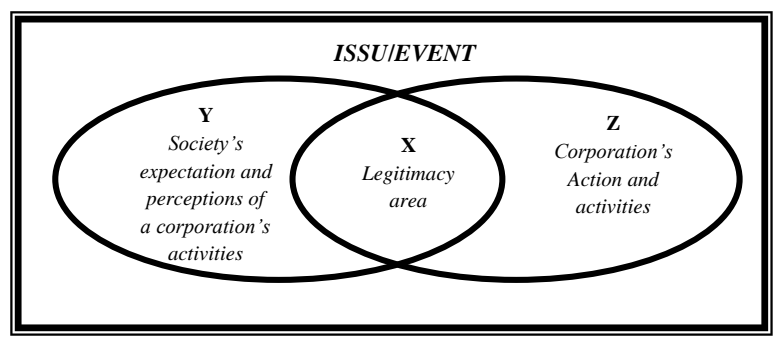

Sumber : Gary O’Donovan (2002) dalam Hadi (2011)

Gambar 1: Daerah Legitimacy Gap

\subsection{Teori keagenan (Agency Theory)}

Eisenhardt (1989) menyatakan bahwa teori agensi menggunakan tiga asumsi sifat manusia yaitu: (1) manusia pada umumya mementingkan diri sendiri (self interest), (2) manusia memiliki daya pikir terbatas mengenai persepsi masa mendatang (bounded rationality), dan (3) manusia selalu menghindari resiko (risk averse). Berdasarkan asumsi sifat dasar manusia tersebut manajer sebagai manusia akan bertindak opportunistic, yaitu mengutamakan kepentingan pribadinya (Haris, 2004, dalam Ujiyantho et al. 2007).

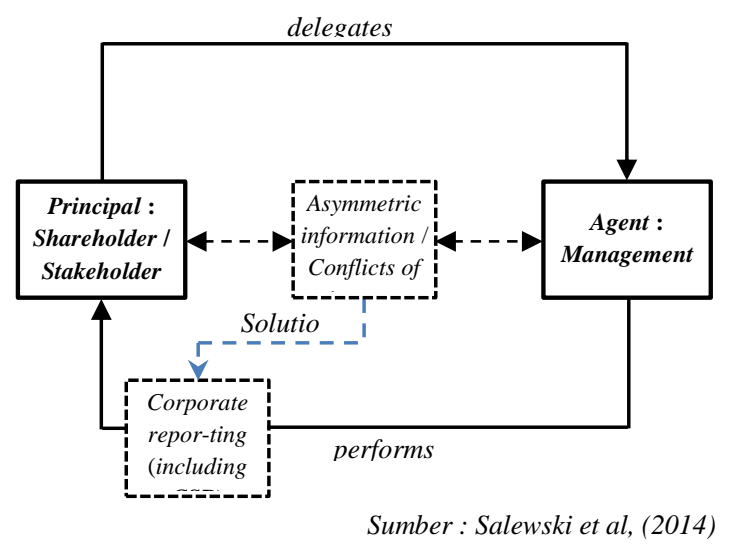

Gambar 2: CSR dalam pandangan agency theory

Berkenaan dengan principle agent theory (Jensen dan Meckling, 1976), pelaporan 
perusahaan sering dianggap sebagai solusi untuk mengurangi asimetri informasi dan konflik kepentingan antara principle (pemilik), yaitu pemegang saham, dan agent, yaitu manajemen (Ruhnke dan Simons, 2012, dalam Salewski et al., 2014). Jika principle agent theory dilengkapi dengan stakeholder theory, principle mungkin juga mewakili pemangku kepentingan lainnya seperti masyarakat atau pemerintah. Dalam hal ini, pelaporan CSR mungkin mengurangi asimetri informasi yang berkaitan dengan kinerja sosial dan lingkungan perusahaan (Salewski et al., 2014).

\section{4. $\quad C S R$ di Indonesia}

Merujuk pada Saidi dan Abidin (2004) dalam Suharto (2006) sedikitnya ada empat model atau pola $C S R$ yang umumnya diterapkan oleh perusahaan di Indonesia.

1. Keterlibatan langsung. Perusahaan menjalankan program CSR secara langsung dengan menyelenggarakan sendiri kegiatan sosial atau menyerahkan sumbangan ke masyarakat tanpa perantara.

2. Melalui yayasan atau organisasi sosial perusahaan. Perusahaan mendirikan yayasan sendiri dibawah perusahaan atau groupnya. Model ini merupakan adopsi dari model yang lazim diterapkan di perusahaan-perusahaan di negara maju

3. Bermitra dengan pihak lain. Perusahaan menyelenggarakan CSR melalui kerjasama dengan lembaga sosial/organisasi nonpemerintah (Ornop), instansi pemerintah, universitas atau media massa, baik dalam mengelola dana maupun dalam melaksanakan kegiatan sosialnya.

4. Mendukung atau bergabung dalam suatu konsorsium. Perusahaan turut mendirikan, menjadi anggota atau mendukung suatu lembaga sosial yang didirikan untuk tujuan sosial tertentu.

\subsection{Kualitas Laba (Earnings Quality)}

Kualitas laba merupakan konsep yang bersifat teoritis dan multidimensi. Hasil sejumlah penelitian yang pernah dilakukan belum mengidentifikasikan suatu metode yang seragam untuk mengukur konsep ini (Wardhani, 2009).

Bellovary et al. (2005) dalam Surifah (2010) mendefinisikan kualitas laba sebagai kemampuan laba dalam merefleksikan kebenaran laba perusahaan dan membantu memprediksi laba mendatang, dengan mempertimbangkan stabilitas dan persistensi laba. Laba mendatang merupakan indikator kemampuan membayar deviden masa mendatang.

\subsection{Pengukuran Kualitas Laba}

Francis et al. (2004), membagi dua kelompok besar atribut kualitas pelaporan keuangan, yaitu accounting-based dan marketbased. Atribut kualitas pelaporan keuangan berdasarkan akuntansi adalah kualitas akrual, persistensi, prediktabilitas, dan perataan laba. Sedangkan untuk atribut kualitas pelaporan keuangan berbasis pasar terdiri dari relevansi, ketepatan waktu, dan konservatisme.

\subsection{Rerangka Pemikiran}

Dalam penelitian ini kualitas laba diukur dengan menggunakan tiga pendekatan, yaitu: (1) pengukuran tingkat manajemen laba dengan menggunakan conditional revenue model; pengukuran accrual persistence dan (3) pengukuran quality of accruals. Dan berdasarkan penelitian sebelumnya yang menemukan bahwa size (ukuran perusahaan), leverage (rasio ungkitan) dan growth (kesempatan pertumbuhan) dapat memengaruhi luas pengungkapan informasi, termasuk pengungkapan $C S R$, maka dalam penelitian ini, size, leverage dan growth digunakan sebagai variabel kontrol.

\subsection{Hipotesis}

Pengukuran kualitas laba dalam penelitian ini digunakan tiga pendekatan, yaitu, (1) pengukuran tingkat manajemen laba dengan menggunakan salah satu dari dua model pengukuran yang dikembangkan oleh Stubben (2010), yaitu conditional revenue model; (2) pengukuran persistensi akrual (accrual persistence), dan (3) pengukuran kualitas akrual (quality of accruals).

\section{Pengaruh $C S R$ terhadap kualitas laba yang diukur dengan conditional revenue model (CRM)}

Menurut Messier et al. (2008) hubungan keagenan dalam pandangan agency theory ini mengakibatkan dua permasalahan, yaitu (1) terjadinya asimetri informasi (information asymmetry), dan (2) terjadinya konflik kepentingan (conflict of interest). Ruhnke dan Simons (2012), dalam Salewski et al. (2014) menyatakan bahwa pelaporan perusahaan sering dianggap sebagai solusi untuk mengurangi asimetri informasi dan konflik kepentingan antara 
principle, yaitu pemegang saham, dan agent, yaitu manajemen. Kemudian Salewski (2014) mengemukakan bahwa pelaporan CSR mungkin akan mengurangi adanya asimetri yang berkaitan dengan kinerja sosial dan lingkungan perusahaan.

Beberapa penelitian yang menunjukkan bahwa akitivitas CSR terbukti berpengaruh negatif terhadap aktivitas, pengaruh negatif tersebut mempunyai dampak baik pada kualitas pelaporan keuangan, yaitu melaporkan laba yang lebih berkualitas.

Berdasarkan paparan rerangka pemikiran diatas, dan hasil penelitian sebelumnya, maka hipotesis pertama yang diajukan adalah :

\section{$\mathrm{H}_{1}$ : Terdapat pengaruh yang negatif antara $C S R$ terhadap kualitas laba yang diukur dengan Conditional Revenue Model (CRM)}

\section{Pengaruh $C S R$ terhadap kualitas laba yang diukur dengan pengukuran Accrual Persistence}

Sama seperti pada aktivitas manajemen laba bahwa persistensi akrual ditentukan oleh diskresi manajemen dalam mengelola kebijakan akuntansinya. Sehingga motivasi manajer untuk bersikap jujur, dapat dipercaya dan beretika, akan menentukan kualitas pelaporan keuangan untuk melayani kepentingan seluruh stakeholders. Aktivitas CSR yang merupakan manifestasi dari etika bisnis, akan memengaruhi budaya perusahaan ke arah bisnis yang beretika, termasuk dalam menjaga hubungan dengan para stakeholders, dengan menyiapkan laporan kinerja perusahan yang lebih baik sebagai wujud akuntabilitas dan keterbukaan operasi perusahaan.

Penelitian Laksmana et al. (2009) dalam Salewski et al, (2014) menemukan pengaruh positif antara CSR dan kualitas laba yang diukur dengan earnings predictability, smoothness, persistence dan accrual quality. Mereka berpendapat bahwa perusahaan dengan CSR tinggi memiliki penghasilan yang lebih dapat diprediksi (predictability), lebih persistensi (persistence) dan melaporkan laba yang stabil (smoother) dari pada pendapatan perusahaan dengan $C S R$ yang lebih rendah.

Berdasarkan paparan rerangka pemikiran diatas, dan hasil penelitian sebelumnya, maka hipotesis kedua yang diajukan adalah :

\section{$\mathrm{H}_{2}$ : Terdapat pengaruh yang positif antara CSR terhadap kualitas laba, yang diukur dengan Acrual Persistence}

\section{Pengaruh $C S R$ terhadap kualitas laba yang diukur dengan pengukuran Quality of Accruals}

Penggunaan model kualitas akrual tersebut berdasarkan dari prinsip akuntansi yaitu basis akrual (accrual basis). Beberapa penelitian yang menunjukkan bahwa akitivitas $C S R$ terbukti berpengaruh positif terhadap kualitas laba yang diukur dengan kualitas akrual adalah hasil penelitian Laksmana et al. (2009), demikian juga dengan hasil penelitian Hong dan Andersen (2011), serta hasil penelitian Choi dan Pae (2011).

Berdasarkan paparan rerangka pemikiran diatas, dan hasil penelitian sebelumnya, maka hipotesis ketiga yang diajukan adalah :

\section{$\mathrm{H}_{3} \quad$ : Terdapat pengaruh yang positif antara $C S R$ terhadap kualitas laba, yang diukur dengan Quality of Acruals}

\section{METODE PENELITIAN}

\subsection{Populasi dan Sampel Penelitian}

Penelitian ini menggunakan data sekunder yang diunduh dari website Bursa Efek Indonesia (BEI) dan diunduh dari masing-masing website perusahaan yang termasuk dalam populasi penelitian. Adapun data sekunder yang diunduh adalah data laporan keuangan, laporan $C S R$ dan laporan keberlanjutan (Sustainability Report) perusahaan-perusahaan selain industri keuangan yang listing di Bursa Efek Indonesia mulai tahun 2009 sampai dengan 2013. Dalam pemilihan sampel digunakan metode purposive sampling. Prosedur seleksi perusahaan-perusahaan untuk dijadikan sampel disajikan pada Tabel 1 dibawah ini. 
Tabel 1 : Prosedur Seleksi Sampel

No.

Kriteria

Jumlah

Perusahaan

1 Perusahaan (selain industri keuangan) yang terdaftar di BEI tahun 2009 sampai dengan tahun 2013

2 Perusahaan yang membuat buku laporan keberlanjutan (Sustainability

Reporting) atau buku laporan CSR (Corporate Social Responsibility

Reporting) dalam bentuk file pdf dan dapat diunduh di website

perusahaan tersebut

3 Perusahaan tidak mempunyai data lengkap sesuai dengan variabelvariabel yang digunakan dalam penelitian ini.

4 Perusahaan delisting selama periode 1 Januari 2009-31 Desember 2013

5 Laporan keuangan disajikan dalam mata uang asing.

\section{Sampel Penelitian}

\subsection{Model Empiris Penelitian}

Tujuan dari penelitian kausal adalah untuk mengidentifikasi hubungan sebab akibat antara variabel-variabel yang berfungsi sebagai penyebab dan variabel mana berfungsi sebagai variabel akibat. Dalam penelitian ini Corporate Social Responsibility dipengaruhkan terhadap kualitas laba.

\section{- Model Pertama}

Untuk menguji hipotesis pengaruh Corporate Social Responsibility terhadap kualitas laba, digunakan alat analisis regresi berganda, dengan model persamaan sebagai berikut :

$C R M_{i t}=\alpha_{0}+\beta_{1} C S D I_{i t}+\beta_{2} S I Z E_{i t}+\beta_{3} L E V E R A G E_{i t}+\beta_{4} G R O W T H_{i t}+\varepsilon_{i t}$

\section{- $\quad$ Model Kedua}

$$
A P_{i t}=\alpha_{0}+\beta_{1} C S D I_{i t}+\beta_{2} \operatorname{SIZE}_{i t}+\beta_{3} L_{E V E R A G E}+\beta_{4} G R O W T H_{i t}+\varepsilon_{i t}
$$

\section{- $\quad$ Model Ketiga}

$Q o A_{i t}=\alpha_{0}+\beta_{1} C S D I_{i t}+\beta_{2} \operatorname{SIZE}_{i t}+\beta_{3} L E V E R A G E_{i t}+\beta_{4} G R O W T H_{i t}+\varepsilon_{i t}$

Keterangan :

$\begin{array}{ll}C R M & =\text { Conditional Revenue Model } \\ A P & =\text { Accrual Persistence }\end{array}$ 


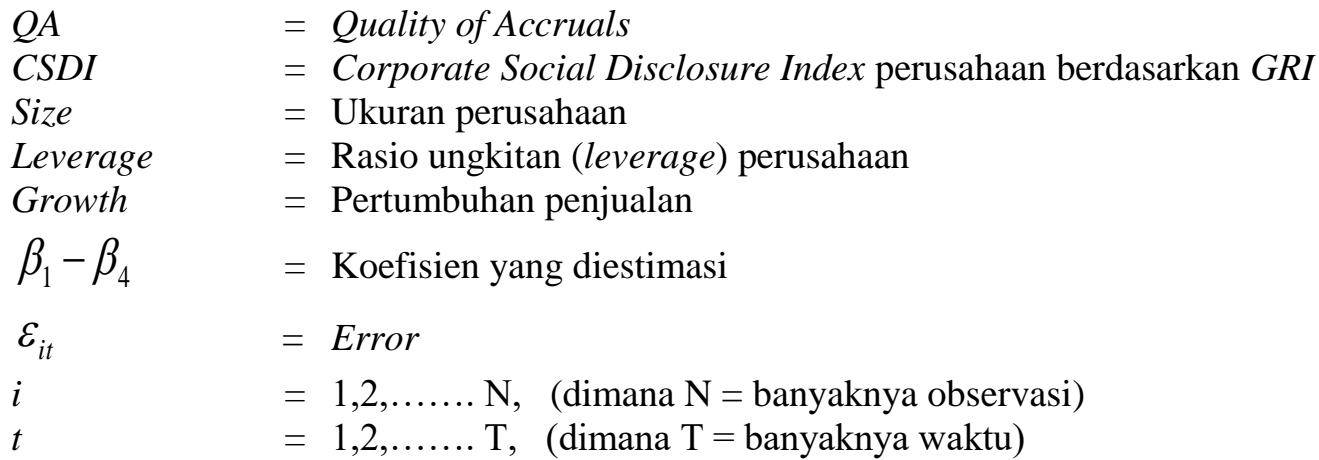

\subsection{Definisi dan Operasionalisasi Variabel}

$$
\varepsilon \quad=\text { error }
$$

\subsubsection{Variabel Dependen $(Y)$}

Variabel dependen $(Y)$ dalam penelitian ini adalah kualitas laba. Dalam penelitian ini kualitas laba diukur dengan menggunakan tiga pendekatan yang berbeda, yaitu (1) Conditional Revenue Model, (Stubben, 2010) sebagai proksi dalam mendeteksi tingkat manajemen laba, (2) Accrual Persistence (Givoly,2010), dan (3) Quality of accruals (Sivaramakrishnan et al., 2008).

\subsubsection{Conditional Revenue Model $\left(Y_{1}\right)$}

Untuk mengukur atau mendeteksi tingkat manajemen laba, dalam penelitian ini digunakan pendekatan Conditional Revenue Model yang menekankan pada banyak aspek yang memengaruhi pendapatan diskresioner. Aspek tersebut meliputi ukuran perusahaan (Size), umur perusahaan (Age), dan laba kotor (Gross Revenue Margin). Formula Conditional Revenue Model, Stubben (2010) adalah sebagai berikut :

\subsubsection{Accrual Persistence $\left(Y_{2}\right)$}

Pengukuran persistensi akrual (accrual persistence) digunakan model Givoly et al. (2010), yaitu dengan menggunakan regresi sebagai berikut

$$
O I_{i, t+1}=\alpha+\beta_{1} C F_{i, t}+\beta_{2} A C C R_{i, t}+\varepsilon_{i, t}
$$

Keterangan :

$$
\begin{aligned}
O I_{i, t+1}= & \begin{array}{l}
\text { Pendapatan operasi } \\
\end{array} \\
& \begin{array}{r}
\text { Operating Income }) \\
\text { setelah } \\
\text { depreasiasi perusahaan } i \\
\text { pada tahun } t+1
\end{array} \\
C F_{i, t}= & \text { Komponen arus kas } \\
& \text { operasi (Cash Flow) dari }
\end{aligned}
$$

$$
\begin{aligned}
& \Delta A R_{i t}=\alpha+\beta_{1} \Delta R_{i t}+\beta_{2} \Delta R_{i t} \times S I Z E+\beta_{3} \Delta R_{i t} \times A G E_{i t}+\beta_{4} \Delta R_{i t} \times A G \text { laba perusahaan } i \text { pada } \\
& +\beta_{5} \Delta R_{i t} \times G R R_{-} P_{i t}+\beta_{6} \Delta R_{i t} \times G R R_{-} N_{i t}+\beta_{7} Q R R_{i t} \times G R M M_{i t} \text { Komponen laba akrual } \\
& +\beta_{8} \Delta R_{i t} \times G R M_{-} S Q_{i t}+\varepsilon_{i t}
\end{aligned}
$$

SIZE $\quad=$ Natural log dari total aset

akhir tahun

$$
\begin{array}{ll}
A G E & =\text { Umur perusahaan (tahun) } \\
G R R \_P & =\text { Industry median adjusted }
\end{array}
$$

revenue growth $(0=$ if negative $)$

$G R R \_N=$ Industry median adjusted

revenue growth $(0=$ if positive $)$

GRM = Margin kotor yang

disesuaikan pada akhir tahun fiskal

$S Q \quad=$ Kuadrat dari variabel

$\Delta \quad=$ Perubahan tahunan
Variabel-variabel dalam regresi tersebut distandarisasi oleh $N O A_{t-1}$. Kontribusi tambahan akrual ditentukan oleh besarnya signifikansi $\beta_{2}$. Dalam penelitian ini nilai NOA sama dengan Debt + Equity - Cash - Minority Interest.

\subsubsection{Quality of accruals $\left(Y_{3}\right)$}


Pengukuran quality of accruals dalam penelitian ini menggunakan model Sivaramakrishnan dan $Y u$ (2008) dalam Surifah (2010), yang merupakan modelnya Dechow dan Dichev (2002) yaitu model regresi current accruals yang di lag-kan dengan arus kas operasi saat ini dan mendatang. Rumusnya adalah sebagai berikut :

$$
\frac{\operatorname{TACC}_{i, t}}{\operatorname{ASSETS~}_{i, t}}=\beta_{0, i}+\beta_{1, i} \frac{\operatorname{CFO}_{i, t-1}}{\operatorname{ASSETS~}_{i, t-1}}+\beta_{2, i} \frac{\operatorname{CFO}_{i, t}}{\operatorname{ASSETS~}_{i, t}}+\beta_{3, i} \frac{\operatorname{CFO}_{i, t+1}}{\operatorname{ASSETS~}_{i, t+1}}+V_{i, t}
$$

Dimana TACC adalah total current accruals yang diskala dengan total assets.

$$
T A C C=\triangle C A-\triangle C L-\triangle C a s h+\triangle S T D E B T
$$

Arus kas dari operasi, CFO (Cash Flow from Operations), dihitung dari laba bersih sebelum pos luar biasa dikurangi total accruals.

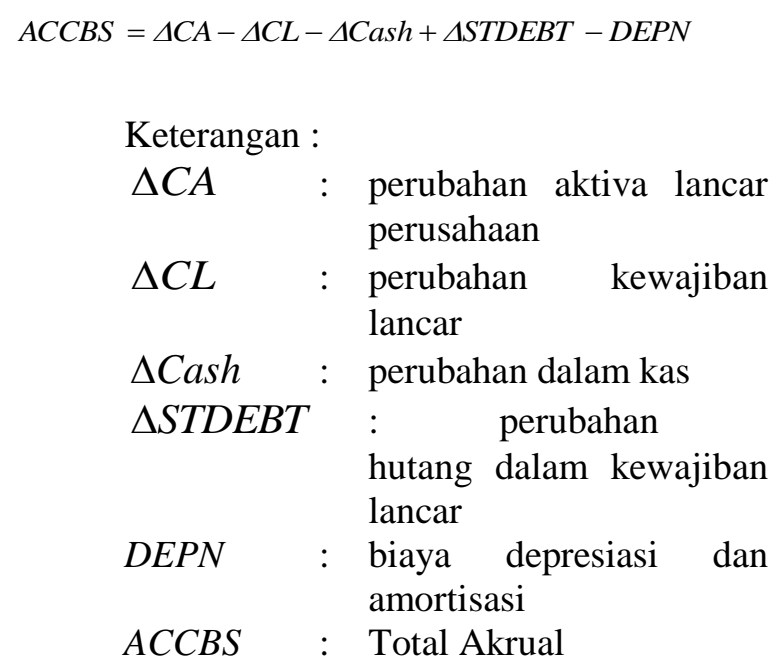

Standar deviasi perusahaan residual-nya diestimasi sebagai kebalikan dari kualitas akrual.

$$
I N V A C C Q=\sigma\left(\widehat{v}_{i t}\right)
$$

Besarnya nilai INVACCQ menunjukkan rendahnya kualitas akrual.

\subsubsection{Variabel Independen $(X)$}

Variabel independen $(X)$ dalam penelitian ini adalah Corporate Social Responsibility Index (CSDI). Dalam pengukuran CSR mengacu pada instrumen Global Reporting Initiative (GRI) yang diperoleh dari www.globalreporting.org. Perhitungan CSDI (Corporate Sosial Disclosure Index) dihitung dengan menggunakan rumus sebagai berikut (Haniff et al. (2005) dalam Sayekti dan Wondabio (2007)):

$$
C S D I_{j}=\frac{\sum X_{i j}}{n_{j}}
$$

Dimana :

CSDI $_{j} \quad$ : Corporate Social

Responsibility Disclosure Index perusahaan $\mathrm{j}$

$n_{j} \quad:$ jumlah item untuk

perusahaan $\mathrm{j}, n_{j}=91$

$X_{i j} \quad: 1=$ jika item $\mathrm{i}$

diungkapkan; $0=$ jika item i tidak

diungkapkan

Dengan demikian, $\mathrm{O}<C S D I_{j}<1$

\subsubsection{Variabel Kontrol}

\subsubsection{Size}

Size merupakan natural log dari nilai pasar ekuitas, Size diukur dengan menggunakan rumus sebagai berikut :

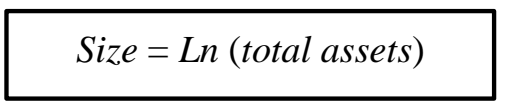

Keterangan : Ln total assets adalah natural logarithma dari total assets.

\subsubsection{Leverage}

Leverage perusahaan dalam penelitian ini diukur dengan rumus:

$$
\text { Leverage }=\frac{\text { Nilai buku total kewajiban }}{\text { Total Assets }}
$$

\subsubsection{Growth (Pertumbuhan Perusahaan)}

Proksi dari pertumbuhan penjualan adalah penjualan tahun ke $t$ dikurangi penjualan tahun $t-1$ dibagi penjualan $t-1$. Pertumbuhan penjualan dihitung dengan rumus sebagai berikut :

$$
P P=\frac{\text { Sales }_{t}-\text { sales }_{t-1}}{\text { sales }_{t-1}}
$$

\section{HASIL DAN PEMBAHASAN}

4.1. Hasil

\subsubsection{Uji Normalitas}


Pengujian normalitas data dilakukan dengan analisis grafik Normal P-P Plot, dan hasilnya seperti pada Gambar 4 dibawah ini.

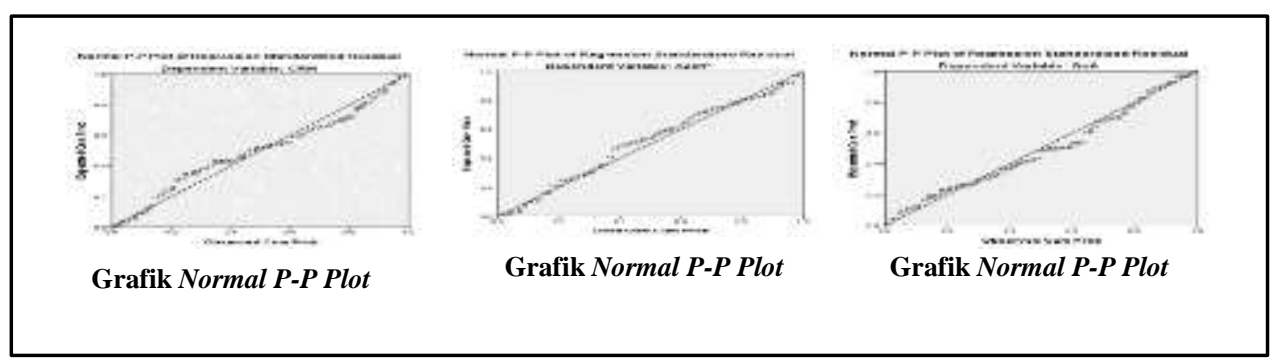

\subsubsection{Uji Multikolinearitas}

Model regresi yang baik seharusnya tidak terjadi korelasi diantara variabel independen. Jika variabel independen saling berkorelasi, maka variabel-variabel ini tidak orthogonal (Ghozali, 2013). Hasil pengujian multikolinearitas disajikan pada Tabel 2 di bawah

Tabel 2 : Hasil Pengujian Multikolinearitas

\begin{tabular}{|c|c|c|c|c|}
\hline \multirow{2}{*}{$\begin{array}{c}\text { Model } \\
\text { Penelitian }\end{array}$} & \multirow[b]{2}{*}{ Variabel } & \multirow{2}{*}{$\begin{array}{c}\text { Nilai } \\
\text { Tolerance }\end{array}$} & \multirow{2}{*}{$\begin{array}{l}\text { Nilai } \\
\text { VIF }\end{array}$} & \multirow[b]{2}{*}{ Hasil Uji } \\
\hline & & & & \\
\hline \multirow[t]{5}{*}{ Model-1 } & (Constant) & & & \\
\hline & $C S D I_{t}$ & .909 & 1.101 & Bebas multikolinearitas \\
\hline & $\operatorname{SIZE}_{t}$ & .992 & 1.008 & Bebas multikolinearitas \\
\hline & $L_{L E V E R A G E_{t}}$ & .906 & 1.104 & Bebas multikolinearitas \\
\hline & $\mathrm{GROWTH}_{t}$ & .968 & 1.033 & Bebas multikolinearitas \\
\hline \multirow[t]{5}{*}{ Model-2 } & (Constant) & & & \\
\hline & $C S D I_{t}$ & .882 & 1.134 & Bebas multikolinearitas \\
\hline & $S I Z E_{t}$ & .998 & 1.002 & Bebas multikolinearitas \\
\hline & $L_{L E V E R A G E_{t}}$ & .878 & 1.139 & Bebas multikolinearitas \\
\hline & $\mathrm{GROWTH}_{t}$ & .970 & 1.031 & Bebas multikolinearitas \\
\hline \multirow[t]{5}{*}{ Model-3 } & (Constant) & & & \\
\hline & $C S D I_{t}$ & .899 & 1.113 & Bebas multikolinearitas \\
\hline & $S I Z E_{t}$ & .990 & 1.010 & Bebas multikolinearitas \\
\hline & $L_{L E V E R A G E_{t}}$ & .904 & 1.107 & Bebas multikolinearitas \\
\hline & $\mathrm{GROWTH}_{t}$ & .974 & 1.027 & Bebas multikolinearitas \\
\hline
\end{tabular}

Sumber : Hasil Olah SPSS 23.0 


\subsubsection{Uji Heteroskedastisitas}

Model regresi yang baik adalah yang homoskedastisitas atau tidak terjadi heteroskedatisitas. Berikut adalah grafik plot antara nilai prediksi variabel terikat (dependen) yaitu ZPRED dengan residualnya SRESID, hasil olah SPSS 23.0 untuk mendeteksi heteroskedastisitas pada model penelitian pertama, kedua dan ketiga (Model-1, Model-2 dan Model$3)$.

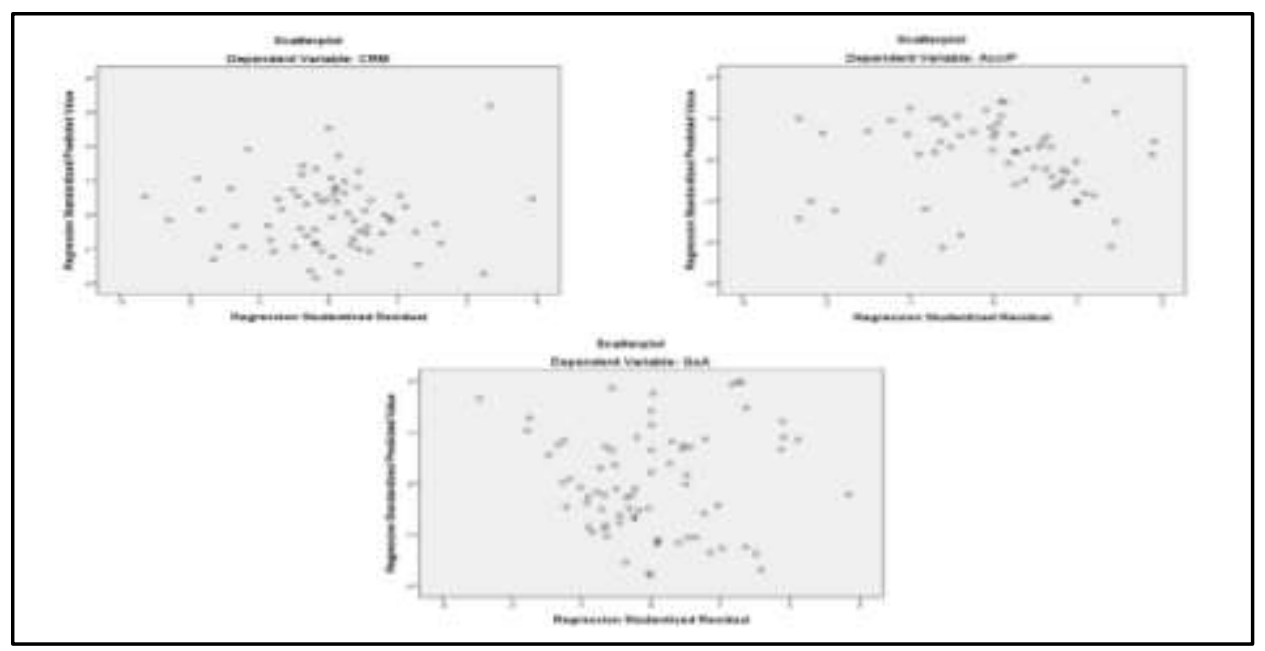

Gambar 2: Grafik Scatterplot Model Penelitian Pertama, Kedua dan

Dari ketiga grafik scatterplots di atas terlihat bahwa titik-titik menyebar secara acak serta tersebar baik di atas maupun di bawah angka 0 pada sumbu Y. Dengan demikian dapat disimpulkan bahwa tidak terjadi heteroskedastisitas pada model penelitian pertama, model penelitian kedua dan model penelitian ketiga.

\subsubsection{Pengujian Hipotesis}

\subsubsection{Pengujian Hipotesis Model Penelitian Pertama (Model-1)}

\subsection{Uji Koefisien Determinasi}

Hasil uji Koefisien determinasi $\left(R^{2}\right)$ untuk model penelitian pertama disajikan pada Tabel 3 berikut ini :

Tabel 3 : Koefisien Determinasi Model Penelitian Pertama (Model-1)

\begin{tabular}{|c|c|c|c|c|}
\hline Model & $\mathbf{R}$ & R Square & $\begin{array}{l}\text { Adjusted } \\
\text { R Square }\end{array}$ & $\begin{array}{l}\text { Std. Error of } \\
\text { the Estimate }\end{array}$ \\
\hline & $.475^{\mathrm{a}}$ & .226 & .179 & .47867590 \\
\hline
\end{tabular}

Sumber : Output SPSS

Berdasarkan Tabel 3 di atas, dapat dilihat nilai $R$ adalah $47,5 \%$ artinya hubungan variabel independen memiliki korelasi yang cukup ( $>25-$
$50 \%$ ), dan nilai $R$ Square adalah sebesar 22,6\% artinya adalah keempat variabel independen yaitu, CSDI, SIZE, LEVERAGE dan GROWTH secara 
bersama-sama dapat menjelaskan variabilitas Conditional Revenue Model (CRM) dan sisanya sebesar $77,4 \%$ dijelaskan oleh sebab-sebab lain yang tidak dibahas dalam penelitian ini. Kemudian nilai Adjusted $R$ Square pada Tabel 3 di atas menunjukkan nilai sebesar $17,9 \%$, hal ini juga berarti bahwa keempat variabel independen yaitu, CSDI, SIZE, LEVERAGE dan GROWTH secara bersama-sama dapat menjelaskan variabilitas dari Conditional Revenue Model (CRM) sebesar 17,9\% dan sisanya sebesar $82,1 \%$ dijelaskan oleh sebab- sebab lain yang tidak dibahas dalam penelitian ini. Std. Error of the Estimate sebesar 0.47867590. Semakin kecil nilai Std. Error of the Estimate, maka semakin tepat model regresi dalam memprediksi variabel dependen.

\subsection{Uji $F$ Statistik}

Hasil uji $F$ Statistik untuk model penelitian pertama disajikan pada Tabel 4 berikut ini :

Tabel 4 : Hasil Uji F Statistik Model Penelitian Pertama (Model-1)

\begin{tabular}{|c|c|c|c|c|c|}
\hline Model & $\begin{array}{c}\text { Sum of } \\
\text { Squares }\end{array}$ & df & $\begin{array}{l}\text { Mean } \\
\text { Square }\end{array}$ & $\mathbf{F}$ & Sig. \\
\hline 1 Regression & 4.406 & 4 & 1.101 & $\begin{array}{r}4.80 \\
7\end{array}$ & $.002^{\mathrm{b}}$ \\
\hline Residual & 15.123 & 66 & .229 & & \\
\hline Total & 19.529 & 70 & & & \\
\hline \multicolumn{6}{|c|}{ a. Dependent Variable: $C R M$} \\
\hline
\end{tabular}

Sumber : Output SPSS

Berdasarkan Tabel 4 dapat dilihat nilai $F$ hitung sebesar 4.807 dengan nilai probabilitas signifikansi lebih kecil dari $5 \%(0,05)$ yaitu sebesar 0,002. Dengan demikian hipotesis dapat diterima dan terdapat pengaruh yang signifikan antara variabel independen (CSDI, SIZE, LEVERAGE dan GROWTH) terhadap variabel dependen, yaitu Conditional Revenue Model $(C R M)$.

\subsection{Uji $t$ Statistik}

Hasil regresi untuk model penelitan pertama disajikan pada Tabel 5 berikut ini.

Tabel 5 : Hasil Regresi Model Penelitian Pertama (Model-1)

$$
C R M_{t}=\alpha+\beta_{1} C S D I_{t}+\beta_{2} S I Z E_{t}+\beta_{3} L E V E R A G E_{t}+\beta_{3} G R O W T H_{t}+\varepsilon_{t}
$$

\begin{tabular}{|c|c|c|c|c|c|}
\hline Model & B & Std. Error & Beta & $\mathbf{t}$ & Sig. \\
\hline 1 (Constant) & 0.626 & 1.001 & & 0.626 & 0.534 \\
\hline CSDI & -0.649 & 0.253 & -0.292 & -2.570 & 0.012 \\
\hline SIZE & $-0,017$ & 0.057 & -0.032 & -0.297 & 0.768 \\
\hline
\end{tabular}

Unstandardized Coefficients Coefficients 


\begin{tabular}{cccccc} 
LEVERAGE & -0.660 & 0.292 & -0.257 & -2.257 & 0.027 \\
\hline GROWTH & 0.864 & 0.328 & 0.290 & 2.633 & 0.011
\end{tabular}

a. Dependent Variable: $C R M$

Sumber : Output SPSS

Persamaan regresi yang terbentuk untuk model penelitian pertama adalah sebagai berikut :

$$
C R M_{t}=0,626-0,649 C_{S D I}-0,017 \text { SIZE }_{t}-0,660 \text { LEVERAGE }_{t}
$$

$$
+0,864 \mathrm{GROWTH}_{t}
$$

\subsubsection{Pengujian Hipotesis Model Penelitian \\ Kedua (Model-2)}

Hasil uji Koefisien determinasi $\left(R^{2}\right)$ untuk model penelitian kedua disajikan pada Tabel 6 berikut ini:

\subsection{Uji Koefisien Determinasi}

Tabel 6 : Koefisien Determinasi Model Penelitian Kedua (Model-2)

\begin{tabular}{|c|c|c|c|c|}
\hline Model & $\mathbf{R}$ & R Square & $\begin{array}{l}\text { Adjusted } \\
\text { R Square }\end{array}$ & $\begin{array}{l}\text { Std. Error of } \\
\text { the Estimate }\end{array}$ \\
\hline & $.389^{\mathrm{a}}$ & .151 & .093 & 1.020151 \\
\hline \multicolumn{5}{|c|}{$\begin{array}{l}\text { a. Predictors: (Constant), GROWTH, SIZE, CSDI, LEVERAGE } \\
\text { b. Dependent Variable: AccrP }\end{array}$} \\
\hline
\end{tabular}

\section{Model Summary ${ }^{b}$}

Berdasarkan Tabel 6 di atas, dapat dilihat nilai $R$ adalah $38,9 \%$ artinya hubungan variabel independen memiliki korelasi yang cukup $(>25-$ $50 \%$ ), dan nilai $R$ Square adalah sebesar $15,1 \%$ artinya adalah keempat variabel independen yaitu CSDI, SIZE, LEVERAGE dan GROWTH secara bersama-sama dapat menjelaskan variabilitas dari Accrual Persistence (AccrP) dan sisanya sebesar $84,9 \%$ dijelaskan oleh sebab-sebab lain yang tidak dibahas dalam penelitian ini. Kemudian nilai Adjusted $R$ Square pada Tabel 6 di atas menunjukkan nilai sebesar $9,3 \%$, hal ini juga berarti bahwa keempat variabel independen yaitu CSDI, SIZE, LEVERAGE dan GROWTH secara bersama-sama dapat menjelaskan variabilitas dari Accrual Persistence (AccrP) sebesar 9,3\% dan sisanya sebesar $90,7 \%$ dijelaskan oleh sebab-sebab lain yang tidak dibahas dalam penelitian ini. Std. Error of the Estimate sebesar 1.020151. Semakin kecil nilai Std. Error of the Estimate, maka semakin tepat model regresi dalam memprediksi variabel dependen.

\subsection{Uji $F$ Statistik}

Hasil uji $F$ Statistik untuk model penelitian kedua disajikan pada Tabel 7 berikut ini: 
Tabel 7 : Hasil Uji F Statistik Model Penelitian Kedua (Model-2)

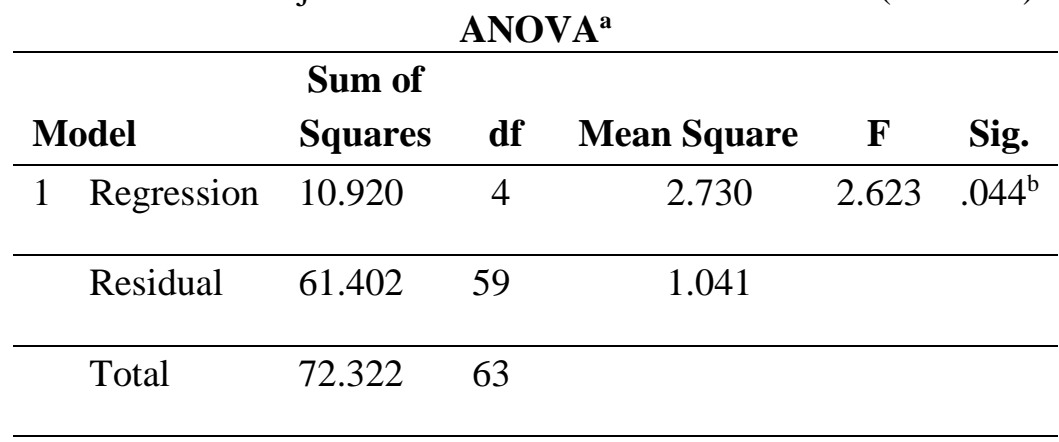

a. Dependent Variable: AccrP

b. Predictors: (Constant), GROWTH, SIZE, CSDI, LEVERAGE

Sumber : Output SPSS

Berdasarkan Tabel 7 dapat dilihat nilai $F$ hitung sebesar 2.623 dengan nilai probabilitas signifikansi lebih kecil dari $5 \%(0,05)$ yaitu sebesar 0,044. Dengan demikian hipotesis dapat diterima dan terdapat pengaruh yang signifikan antara variabel independen (CSDI, SIZE,
LEVERAGE dan GROWTH) terhadap variabel dependen, yaitu Accrual Persistence (AccrP).

\subsection{Uji $t$ Statistik}

Hasil regresi untuk model penelitan kedua disajikan pada Tabel 8 berikut ini.

Tabel 8 : Hasil Regresi Model Penelitian Kedua (Model-2)

$$
\operatorname{AccrP}_{t}=\alpha+\beta_{1} \operatorname{CSDI}_{t}+\beta_{2} \operatorname{SIZE}_{t}+\beta_{3} \text { LEVERAGE }_{t}+\beta_{3} \mathrm{GROWTH}_{t}+\varepsilon_{t}
$$

\begin{tabular}{lccccc}
\hline \multicolumn{7}{c}{} & \multicolumn{5}{c}{ Standardized } \\
\hline Model & B & Std. Error & Beta & $\mathbf{t}$ & Sig. \\
\hline $1 \quad$ (Constant $)$ & 2.781 & 2.216 & & 1.255 & 0.215 \\
\cline { 2 - 6 } & & & & & \\
\hline CSDI & 1.350 & 0.575 & 0.300 & 2.349 & 0.022 \\
\hline SIZE & -0.270 & 0.128 & -0.253 & -2.107 & 0.039 \\
\hline LEVERAGE & 0.655 & 0.682 & 0.123 & 0.961 & 0.341 \\
\hline GROWTH & 0.708 & 0.722 & 0.119 & 0.981 & 0.331 \\
\hline
\end{tabular}

a. Dependent Variable: AccrP

Sumber : Output SPSS

Persamaan regresi yang terbentuk untuk model penelitian kedua adalah sebagai berikut: 


\subsubsection{Pengujian Hipotesis Model Penelitian Ketiga (Model-3)}

\subsection{Uji Koefisien Determinasi}

Tabel 9 : Koefisien Determinasi Model Penelitian Ketiga (Model-3)

$$
\text { Model Summary }{ }^{b}
$$

\begin{tabular}{llccc}
\hline Model & R & R Square & R Square & the Estimate \\
\hline & $.589^{\text {a }}$ & .347 & .310 & .0157344896 \\
\hline & & & \\
\hline a. Predictors: (Constant), GROWTH, SIZE, LEVERAGE, CSDI \\
b. Dependent Variable: QoA \\
Sumber : Output SPSS, Lampiran
\end{tabular}

Berdasarkan Tabel 9 di atas, dapat dilihat nilai $R$ adalah $58,9 \%$ artinya hubungan variabel independen memiliki korelasi yang cukup kuat $(>25-50 \%)$, dan nilai $R$ Square adalah sebesar $34,7 \%$ artinya adalah keempat variabel independen yaitu CSDI, SIZE, LEVERAGE dan GROWTH secara bersama-sama dapat menjelaskan variabilitas dari Quality of Accruals (QoA) dan sisanya sebesar 65,3\% dijelaskan oleh sebab-sebab lain yang tidak dibahas dalam penelitian ini. Kemudian nilai Adjusted $R$ Square pada Tabel 9 di atas menunjukkan nilai sebesar $31,0 \%$, hal ini juga berarti bahwa keempat variabel independen yaitu CSDI, SIZE, LEVERAGE dan GROWTH secara
Hasil uji Koefisien determinasi ( $\left.R^{2}\right)$ untuk model penelitian ketiga disajikan pada Tabel 9 berikut ini: bersama-sama dapat menjelaskan variabilitas dari Quality of Accruals (QoA) sebesar 31,0\% dan sisanya sebesar $69,0 \%$ dijelaskan oleh sebab-sebab lain yang tidak dibahas dalam penelitian ini. Std. Error of the Estimate sebesar 0.0157344896. Semakin kecil nilai Std. Error of the Estimate, maka semakin tepat model regresi dalam memprediksi variabel dependen.

\subsection{Uji $F$ Statistik}

Hasil uji $F$ Statistik untuk model penelitian ketiga disajikan pada Tabel 10 berikut ini:

Tanggal 10 : Hasil Uji F Statistik Model Penelitian Ketiga (Model-3) ANOVA $^{a}$

\begin{tabular}{|c|c|c|c|c|c|c|}
\hline \multicolumn{2}{|c|}{ Model } & \multirow{2}{*}{$\begin{array}{r}\begin{array}{r}\text { Sum of } \\
\text { Squares }\end{array} \\
.009\end{array}$} & \multirow{2}{*}{$\begin{array}{r}\text { df } \\
4\end{array}$} & \multirow{2}{*}{$\begin{array}{r}\begin{array}{c}\text { Mean } \\
\text { Square }\end{array} \\
.002\end{array}$} & \multirow{2}{*}{$\begin{array}{c}\text { F } \\
9.30 \\
0\end{array}$} & \multirow{2}{*}{$\begin{array}{l}\text { Sig. } \\
.000^{b}\end{array}$} \\
\hline 1 & Regression & & & & & \\
\hline & Residual & .017 & 70 & .000 & & \\
\hline & Total & .027 & 74 & & & \\
\hline
\end{tabular}

a. Dependent Variable: QoA

b. Predictors: (Constant), GROWTH, SIZE, LEVERAGE, CSDI

Sumber : Data diolah menggunakan SPSS 23.0

Berdasarkan Tabel 10 dapat dilihat nilai $F$ hitung sebesar 9.300 dengan nilai probabilitas signifikansi lebih kecil dari 5\% (0,05) yaitu sebesar 0,000. Dengan demikian hipotesis dapat 
diterima dan terdapat pengaruh yang signifikan antara variabel independen (CSDI, SIZE,
LEVERAGE dan GROWTH) terhadap variabel dependen, yaitu Quality of Accruals (QoA).

\subsection{Uji $t$ Statistik}

Hasil regresi untuk model penelitan ketiga disajikan pada Tabel 11 berikut ini.

Tabel 11 : Hasil Regresi Model Penelitian Ketiga (Model-3)

\begin{tabular}{|c|c|c|c|c|c|c|}
\hline & & & \multicolumn{4}{|c|}{ Standardized } \\
\hline & & \multicolumn{2}{|c|}{ Unstandardized Coefficients } & \multirow{2}{*}{$\frac{\text { Coefficients }}{\text { Beta }}$} & \multirow[b]{2}{*}{$\mathbf{t}$} & \multirow[b]{2}{*}{ Sig. } \\
\hline \multicolumn{2}{|c|}{ Model } & $\mathbf{B}$ & Std. Error & & & \\
\hline 1 & (Constant) & 0.097 & 0.032 & & 2.999 & 0.004 \\
\hline & $C S D I$ & 0.017 & 0.008 & 0.209 & 2.053 & 0.044 \\
\hline & SIZE & -0.004 & 0.002 & -0.204 & -2.098 & 0.040 \\
\hline & LEVERAGE & -0.030 & 0.009 & -0.327 & -3.214 & 0.002 \\
\hline & GROWTH & -0.035 & 0.011 & -0.323 & -3.304 & 0.002 \\
\hline
\end{tabular}

b. Dependent Variable: $Q o A$

Sumber : Output SPSS

Persamaan regresi yang terbentuk untuk model penelitian ketiga adalah sebagai berikut:

$$
\begin{aligned}
Q o A_{t}= & 0,097+0,017 \text { CSDI }_{t}-0,004 \text { SIZE }_{t}-0,030 \text { LEVERAGE }_{t} \\
& -0,035 \text { GROWTH }_{t}
\end{aligned}
$$

\subsection{Pembahasan}

program CSR suatu perusahaan yang dibuktikan

Hasil analisis deskriptif maupun statistik, disajikan dan dibahas dibawah ini.

\section{Pengaruh $C S R$ terhadap kualitas laba yang diukur dengan Conditional Revenue Model (CRM)}

Hasi uji $F$ statistik pada model penelitian pertama (Model-1) menunjukkan bahwa $F$ statistik sebesar 0,002. Artinya bahwa variabel CSDI, SIZE, LEVERAGE dan GROWTH secara bersamasama dapat memengaruhi variabel CRM. Kemudian hasil uji parsial diperoleh signifikansi $t$ untuk CSDI sebesar 0,012, dengan nilai koefisien sebesar -0.649 , artinya secara statistik variabel CSDI berpengaruh negatif dan signifikan terhadap CRM.

Koefisien negatif tersebut menandakan bahwa program CSR yang dilakukan oleh perusahaan mempunyai dampak yang signifikan terhadap tingkat manajemen laba. Semakin baik dengan dilakukannya CSR yang bertanggungjawab, maka perusahaan tersebut akan memegang nilai dalam berbisnis yang akan mengedepankan prinsip-prinsip fairness, transparency, accountability dan responsibility guna menjaga hubungan dengan para stakeholder. Sehingga perusahaan dengan aktivitas CSR yang baik akan membatasi bahkan menghindar dari aktivitas manajemen laba.

\section{Pengaruh $C S R$ terhadap kualitas laba yang diukur dengan Accrual Persistence}

Hasil uji $F$ statistik pada model penelitian kedua (Model-2) menunjukkan bahwa $F$ statistik sebesar 0,044. Artinya bahwa variabel CSDI, SIZE, LEVERAGE dan GROWTH secara bersamasama dapat memengaruhi variabel AccrP. Kemudian hasil uji parsial diperoleh signifikansi $t$ untuk CSDI sebesar 0,022, dengan nilai koefisien 
sebesar 1.350, artinya secara statistik variabel $C S D I$ berpengaruh positif dan signifikan terhadap AccrP.

Koefisien positif tersebut menandakan bahwa program CSR yang dilakukan oleh perusahaan mempunyai dampak yang signifikan terhadap kualitas pelaporan keuangan yang diproksikan dengan kualitas laba. Perusahaan yang memiliki CSR yang baik memiliki nilai akrual yang lebih persistensi (persistence).

\section{Pengaruh CSR terhadap kualitas laba yang diukur dengan Quality of Accruals}

Hasil uji $F$ statistik pada model penelitian ketiga (Model-3) menunjukkan bahwa $F$ statistik sebesar 0,000. Artinya bahwa variabel CSDI, SIZE, LEVERAGE dan GROWTH secara bersamasama dapat memengaruhi variabel $Q o A$. Kemudian hasil uji parsial diperoleh signifikansi $t$ untuk CSDI sebesar 0,044, dengan nilai koefisien sebesar 0.017 , artinya secara statistik variabel CSDI berpengaruh positif dan signifikan terhadap $Q o A$.

Koefisien positif tersebut menandakan bahwa program CSR yang dilakukan oleh perusahaan mempunyai dampak yang signifikan terhadap kualitas pelaporan keuangan yang diproksikan dengan kualitas laba. Semakin baik program CSR suatu perusahaan, maka semakin baik pula kualitas akrual perusahaan tersebut.

\section{SIMPULAN DAN SARAN}

\subsection{Simpulan}

Penelitian ini menemukan bahwa $C S R$ berpengaruh negatif terhadap tingkat manajemen laba (earnings management), yaitu semakin baik $C S R$, semakin rendah tingkat aktivitas manajemen laba. Selain itu hasil penelitian juga menemukan bahwa CSR berpengaruh positif terhadap persistensi akrual (accrual persistence), yaitu semakin baik $C S R$, nilai akrual semakin lebih persisten (persistence). Yang terakhir hasil penelitian menemukan bahwa CSR berpengaruh positif terhadap kualitas akrual (quality of accruals), yaitu semakin baik $C S R$, semakin baik kualitas akrual.

Penelitian sebelumnya yang sejalan dengan hasil penelitian ini adalah penelitian yang dilakukan oleh Calegari, Chotigeat dan Harjoto (2010), kemudian penelitian yang dilakukan oleh Kim, Park, dan Wier (2012), serta penelitian yang dilakukan oleh Gyungmin (2013). Akan tetapi hasil penelitian ini kontradiktif dengan hasil penelitian yang telah dilakukan Prior et al. (2008) dan Salewski et al. (2014), yang menemukan pengaruh positif antara $C S R$ dengan earnings management, yaitu semakin baik CSR semaking tinggi tingkat aktivitas manajemen laba.

\subsection{Keterbatasan Penelitian dan Saran}

Sebelum menyampaikan saran-saran terkait dengan hasil penelitian, terlebih dahulu disampaikan beberapa kelemahan dan keterbatasan dari penelitian ini, yaitu sebagai berikut:

a. Jumlah sampel yang terbatas, yaitu hanya sebanyak 75 laporan keuangan dari 1.801 perusahaan selain industri keuangan yang terdaftar di BEI, hal ini karena masih sedikitnya perusahaan di Indonesia yang membuat laporan tanggung jawab sosial perusahaan (CSR report) atau laporan keberlanjutan (sustainability report).

b. Pengukuran kinerja $C S R$ yang diukur dengan menggunakan indikator GRI G4 dengan metode content analysis, yaitu penilaiannya hanya menggunakan skala 0 dan 1 , sehingga penilaian ini belum memberikan informasi yang lebih rinci mengenai kulitas pengungkapan yang disajikan oleh masingmasing perusahaan.

c. Adanya unsur subjektivitas dalam proses scoring dengan metode content analysis, sehingga nilai pengungkapan untuk indikator GRI yang sama dapat berbeda dengan peneliti yang lain.

d. Adanya gap antara laporan CSR atau sustainability report suatu perusahaan dengan kinerja nyata program CSR di lapangan.

e. Dalam pengukuran tingkat manajemen laba dengan menggunakan salah satu dari dua model discretionary revenue yang dikembangkan oleh Stubben (2010), yaitu conditional revenue model, tidak memperhatikan laporan laba rugi komprehensif, yaitu laporan laba rugi yang ditambahkan dengan komponen pendapatan komprehensif lain. (PSAK 1 tahun 2009).

Saran-saran yang dapat disampaikan untuk penelitian selanjutnya antara lain:

a. Hasil penelitian tentang pengaruh CSR terhadap kualitas pelaporan keuangan masih kontadiktif (belum konsisten), sehingga perlu adanya pencarian faktor/variabel lain yang memengaruhi hubungan kedua variabel tersebut, sehingga perlu adanya penelitianpenelitian yang baru. 
b. Penelitian tentang persistensi akrual (accrual persistence) juga masih belum banyak dilakukan, sehingga perlu dilakukan lagi penelitian-penelitian yang lebih luas.

c. Penelitian selanjutnya diharapkan menggunakan lebih banyak sample dengan menambah sampel perusahaan yang membuat laporan tahunannya dengan menggunakan pedoman GRI.

d. Saran bagi perusahaan, agar lebih meningkatkan pengungkapan CSR dalam

\section{DAFTAR PUSTAKA}

Anggraini, F. R. R., (2006). Pengungkapan Informasi Sosial dan Faktor-Faktor yang Mempengaruhi Pengungkapan Informasi Sosial dalam Laporan Keuangan Tahunan (Studi Empiris pada Perusahaan-Perusahaan yang Terdaftar di BEl). Padang: Simposium Nasional Akuntansi IX, 23-26 Agustus 2006.

Brigham, \& Houston, (2010). Dasar-Dasar Manajemen Keuangan Buku-1 (1 $1^{\text {th }}$ ed.). Jakarta: Salemba Empat.

Calegari, M. F., Chotigeat, T., \& Harjoto, M. A., (2010). Corporate Social Responsibility and Earnings Reporting. Journal of Current Research in Global Business, Vol. 13, No. 20.

Chih, H. L., Shen, C. H., \& Kang, F. C., (2008). Corporate Social Responsibility, Investor Protection and Earnings Management: Some International Evidence", Journal of Business Ethics, 79, 179-198.

Chrysanti, H., S., (2010). Dasari CSR dengan Etika Bisnis. Diakses Pada 4 Desember 2014 dari World Wide Web: http://www.ti.or.id/ index.php/news/2010/11/22/ dasari-csrdengan-etika- bisnis.

Darwin, A., (2008). Akuntabilitas, Kebutuhan, Pelaporan, dan Pengungkapan CSR Bagi Perusahaan di Indonesia. Economics. Business Accounting Review. Majalah Akuntan Indonesia, Edisi XII, 52-57.

Deegan, C. (2004). Financial Accounting Theory. Sydney: McGraw-Hill Book Company.
CSR report atau sustainability report, seperti pengungkapan dimensi hak azasi manusia, dimensi masyarakat dan dimensi tanggung jawab produk yang masih belum sepenuhnya diungkapkan.

e. Saran bagi regulator, agar dapat membuat kebijakan atau aturan mengenai perlunya audit atas program CSR untuk meminimalkan adanya gap antara laporan CSR atau sustainability report suatu perusahaan dengan kinerja nyata program CSR di lapangan.

Ekowati, L., Prasetyono, \& Wulandari, A., (2014). Pengaruh Profitabilitas, Likuiditas, Growth, dan Media Exposure Terhadap Pengungkapan Tanggungjawab Sosial Perusahaan (Studi Pada Perusahaan Manufaktur yang Terdaftar di BEI Tahun 2010-2012). Mataram: Simposium Nasional Akuntansi 17, Universitas Mataram, Lombok, 24 - 27 September 2014.

Fanani, Z., (2008a). Kualitas Pelaporan Keuangan: Faktor-Faktor Penentu dan Konsekuensi Ekonominya. Depok: The 2nd Accounting Conference, $1 s t$ Doctoral Colloquium and Accounting Workshop, Universitas Indonesia, 4-5 November 2008.

Fanani, Z., Putra, A.Y., \& Prastiwi, A., (2008b). Analisis Pengaruh Volatilitas Arus Kas, Magnitude Accrual, Volatilitas Penjualan, Leverage dan Siklus Operasi terhadap kualitas laba. Depok: The 2nd Accounting Conference, 1st Doctoral Colloquium and Accounting Workshop, Universitas Indonesia, , 4-5 November 2008.

Francis, J., LaFond, R., Olsson, P. M., \& Schipper, K., (2004). Costs of Equity and Earnings Attributes. The Accounting Review, Vol. 79, No. 4, pp. 967-1010.

Ghozali, Imam, (2013). Aplikasi Analisis Multivariate dengan Program IBM SPSS 21, Edisi 7. Semarang: Badan Penerbit Universitas Diponegoro,.

Givoly, D., Hayn, C. K., \& Katz, S. P., (2010). Does Public Ownership of Equity Improve Earnings Quality?. The Accounting Review, Vol. 85, No. 1, pp. 195-225.

Global Reporting Initiative, (2013). Pedoman GRI G4 Bagian 2: Panduan Penerapan - 
Terjemahan dalam Bahasa Indonesia. Diakses Pada 10 Oktober 2014 dari World Wide Web: https://www.globalreporting.org

Godfrey, J., Hodgson, A., Homes, S. \& Tarca, A. (2006). Accounting Theory ( $6^{\text {th }} e d$.). Australia: John Wiley and Sons.

Gunawan, J., (2009). Mengukur Kinerja Tanggung Jawab Sosial Perusahaan. Diakses pada tanggal 19 Desember 2015 dari World Wide Web: http://www.ncsrid.org/2009/09/02/mengukur-kinerjatanggung-jawab-sosial-perusahaan/

Gyungmin, Pyo, \& Lee, H. Y., (2013). The Association Between Corporate Social Responsibility Activities And Earnings Quality: Evidence From Donations And Voluntary Issuance Of CSR Reports. The Journal of Applied Business Research, Vol. 29, No. 3, pg. 945.

Hadi, N. (2011). Corporate Social Responsibility. Edisi Pertama. Cetakan Pertama. Yogyakarta: Graha Ilmu.

Hanafi M. M., \& Halim, A., (2009). Analisis Laporan Keuangan. Edisi Keempat, Jakarta: UPP STIM YKPN.

Handajani, L. Subroto, B., Sutrisno, T., \& Saraswati, E., (2014). Pengungkapan Tanggung Jawab Sosial Perusahaan: Determinan dan Konsekuensi. Mataram: Simposium Nasional Akuntansi 17, Universitas Mataram, Lombok, 24 - 27 September 2014.

Haninun, \& Nurdiawansyah, (2014). Analysis of Effect Size Company, Profitability and Leverage Against Social Responsibility Disclosure of Listed Mining Industry in Indonesia Stock Exchange Period 20092012. Jurnal Akuntansi \& Keuangan, Vol. 5, No. 1, Hal. 1-18, Maret 2014.

Hansen, V., \& Juniarti, (2014). Pengaruh Family Control, Size, Sales Growth dan Leverage terhadap Profitabilitas dan nilai perusahaan pada Sektor Perdagangan, Jasa dan Investasi. Businnes Accounting Review, Vol.2, No.1.

Harahap, S. S., (2010) Analisis Kritis Atas Laporan Keuangan. Jakarta. PT. Raja Grafindo Persada.
Jannah, B. S., (2014). Pengaruh Karakter Perusahaan Terhadap Pengungkapan Tanggung Jawab Sosial (CSRD) Dan Implikasinya Terhadap Nilai Perusahaan. Academia: Universitas Brawijaya.

Jensen M. C., \& Meckling W. H., (1976). Theory of the Firm, Managerial Behavior, Agency Costs and Ownership Structure", Journal of Financial Economics. Vol. 3, No. 4, pp. 305-360.

Kim, Y., Park, M. S., \& Wier, B., (2012). Is Earnings Quality Associated with Corporate Social Responsibility?. Social Science Research Retwork (SSRN) http://ssrn.com/abstract=1899071.

LeBlanc, K., (2014). Corporate Social Responsibility: A Beacon for Top Talent. Chicago: DHR International, (diunduh tanggal 4 Desember 2014).

Messier, W. F., Glover, S. M., \& Prawitt, D. F., (2008), Auditing and Assurance Services: A Systematic Approach $\left(6^{\text {th }}\right.$ ed.). New York: McGraw-Hill.

Novita, (2008). Pengaruh Struktur Kepemilikan Terhadap Luas Pengungkapan Tanggung Jawab Sosial (CSR Disclosure) pada Laporan Tahunan Perusahaan (Studi Empiris pada Perusahaan Publik yang Tercatat di Bursa Efek Indonesia pada Tahun 2006). Jakarta: Tesis, Magister Akuntansi, Universitas Indonesia.

Pagalung, G., (2006). Kualitas Informasi Laba, Faktor-Faktor Penentu dan Konsekuensi Ekonominya. Yogyakarta: Disertasi, Universitas Gadjah Mada.

Patoni, A., \& Lasmana, A. (2018). Pengaruh Harga Saham dan Frekuensi Perdagangan Saham terhadap Bid-Ask Spread (Studi Empiris pada Perusahaan Manufaktur yang Melakukan Stock Split di Bursa Efek Indonesia Selama Periode 2009-2014. Jurnal Akunida, 1(2), 112.

Prior D., Surroca J., \& Tribo J.A., (2008). Are Socially Responsible Managers Really Ethical? Exploring the Relationship Between Earnings Management and Corporate Social Responsibility. Journal compilation (C) 2008 Blackwell Publishing, Vol. 16, No. 3 
Rachman, N. M., Efendi, A., \& Wicaksana, E., (2011). Panduan Lengkap Perencanaan CSR. Jakarta: Penebar Swadaya

Rahman, F., (2013). Tanggung Jawab Sosial Perusahaan di Indonesia: Salah Paham?". Diakses Pada 10 Oktober 2014 dari World Wide Web: http:// www.tempo.co/read/kolom/2013/05/16/ 720/Tanggung-Jawab-Sosial-

Perusahaan-di-Indonesi.

Rahmawati, Suprapti, A.R., Seventi S., (2010). Model Strategi Manajemen Laba pada Perusahaan Publik di Bursa Efek Indonesia: Suatu Pemeriksaan Pergeseran Klasifikasi serta Dampaknya terhadap Kinerja Saham, Pemilihan Metoda Akuntansi dan Pengaturan Waktu Transaksi. Jakarta: Journal Akuntansi, Vol. 14, No.1. www.tarumanagara.ac.id

Roychowdhury, S., (2006). Earnings Management Through Real Activities Manipulation. Journal of Accounting and Economics 42 (2006) 335-370.

Salewski, M., \& Zulch, H., (2014). The Association between Corporate Social Responsibility and Earnings Quality, Evidence from European Blue Chips. Social Science Research Retwork (SSRN): Working Paper Series No. 112.

Sayekti, \& Wondabio, (2007). Pengaruh Csr Disclosure Terhadap Earning Response Coefficient (Suatu Studi Empiris Pada Perusahaan yang Terdaftar Di Bursa Efek Jakarta). Makassar: Simposium Nasional Akuntansi X, 26-28 Juli 2007.

Sembiring, E.R., (2005). Karateristik Perusahaan dan Pengungkapan Tanggung Jawab Sosial: Study Empiris Pada Perusahaan yang Tercatat di Bursa Efek Jakarta. Solo: Simposium Nasional Akuntansi VIII, 15-16 Oktober 2005.

Sikka, P., (2010). Smoke and Mirrors: Corporate Social Responsibility and Tax Avoidance. UK: Centre for Global Accountability. University of Essex.

Sivaramakrishnan K., \& Yu, S.C., (2008). On the Association Between Corporate Governance and Earnings Quality. Social Science Research Retwork (SSRN)

http://ssrn.com/abstract=1014243.
Sekaran, U., (2006). Metodologi Penelitian untuk Bisnis. Edisi 4, Buku 1, Jakarta: Salemba Empat.

Stubben, S. R., (2010). Discretionary Revenues as a Measure of Earnings Management. The Accounting Review, Vol. 85, No. 2, pp. 695-717.

Sugiyono, (2007), "Metode Penelitian Administrasi”, Bandung : Alfabeta.

Suharto, E., (2006). Pekerjaan Sosial Industri, CSR dan ComDev. Bandung: Workshop Tentang Corporate Social Responsibility, Lembaga Studi Pembangunan (LSP)-STKS Bandung, 29 November 2006.

Suharto, E., (2008a). Tanggungjawab Sosial Perusahaan, Apa Itu dan Apa Manfaatnya Bagi Perusahaan?. Jakarta: Seminar Dua Hari CSR , Strategy, Management and Leadership. 13-14 Februari 2008.

Suharto, E., (2008b). Corporate Social Responsibility: Konsep dan Perkembangan Pemikiran. Yogyakarta: Workshop Tanggungjawab Sosial Perusahaan, Universitas Islam Indonesia (UII), 6-8 Mei 2008.

Sunarto, \& Budi, A. P., (2009). Pengaruh Leverage, Ukuran Dan Pertumbuhanperusahaan Terhadap Profitabilitas. TEMA, Vol. 6 Edisi 1, Maret 2009, hal. 86 - 103

Surifah, (2010). Kualitas Laba dan Pengukurannya. Yogyakarta: Jurnal Ekonomi, Manajemen \& Akuntansi, Universitas Cokroaminoto, Vol. 8, No.2, Mei-Agustus 2010, ISSN : 1412-9450.

Sutopo, B., (2007). Manajemen Laba Dan Manfaat Kualitas Laba Dalam Keputusan Investasi. Surakarta: Pidato Pengukuhan Guru Besar dalam Bidang Akuntansi pada Fakultas Ekonomi Universitas Sebelas Maret, 21 Agustus 2007.

Triningtyas, I.A., \& Siregar, S.V., (2014). Pengaruh Kualitas Akrual Terhadap Biaya Utang dan Biaya Ekuitas: Studi pada Perusahaan yang Terdaftar di Bursa Efek Indonesia Tahun 2005-2011. Lombok: Simposium Nasional Akuntansi 17, 24-27 September 2014. 
Ujiyantho, M. A., \& Pramuka, B. A., (2007). Mekanisme Corporate Governance, Manajemen Laba dan Kinerja Keuangan. Makasar: Simposium Nasional Akuntansi X, 26-28 Juli 2007.

Wardhani, R., (2009). Pengaruh Proteksi Bagi Investor, Konvergensi Standar Akuntnasi, Implementasi Corporate Governance, dan Kualitas Audit Terhadap Kualitas Laba: Analisis Lintas Negara di Asia. Jakarta: Disertasi, Program Pasca Sarjana Ilmu Akuntansi, Universitas Indonesia.

Wibisono, D., (2013). Panduan Penyusunan Skripsi, Tesis Dan Disertasi. Jakarta: AndiPublisher

Wibisono, Y., (2007). Membedah Konsep \& Aplikasi Corporate Social Responsibility. Gresik: Fascho.

William, (2012). Pengaruh Pengungkapan Corporate Social Responsibility Berdasarkan Pedoman Global Reporting Initiative Terhadap Nilai Perusahaan. Jakarta: Tesis, Magister Manajemen, Universitas Indonesia.

Windharta, S.W., \& Ahmar, N., (2014). Pengaruh Manajemen Laba Akrual dengan Pendekatan Revenue Discretionary Model terhadap Kinerja Perusahaan. Surabaya: Trikonomika, Vol. 13, No. 1, Juni 2014, Hal. 108-118, ISSN 1411514X (print) / ISSN 2355-7737 (online).

Yuliana, R., Purnomosidhi, B., \& Sukoharsono, E. G., (2008). Pengaruh Karakteristik Perusahaan terhadap Pengungkapan Corporate Social Responsibility (CSR) dan Dampaknya terhadap Reaksi Investor. Jurnal Akuntansi dan Keuangan Indonesia, Vol.5, No. 2, Desember 2008. 